\title{
Preloading and Maintenance of Implant Abutment Screws
}

\author{
Pravinkumar G Patil \\ International Journal of Prosthodontics and Restorative Dentistry (2019): 10.5005/jp-journals-10019-1246
}

The dental abutment screw is a threaded fastener used to connect an abutment to a dental implant. ${ }^{1}$ It is usually torqued to a final seating position. Abutment screw loosening has been considered as one of the most common causes of implant-supported restoration failure, after osseointegration failure. ${ }^{2}$ Improper use of the abutment screw can result in detrimental effects on the supporting bone, components of the implant itself, and the final restoration outcome. As the prosthetic screw is tightened, the torque applied is transferred to the threads of the prosthetic screw and internal threads of the implant and usually referred to as a preload or clamping. In implant dentistry, preload refers to the energy transferred to a screw when a torque is applied during tightening. This stretching keeps the screw threads tightly secured to the screw's mating counterpart and holds them together by producing a clamping force between the screw head and its seat (in the dental implant fixture). ${ }^{1}$ Preload is measured in Newton (N) and principally determined by three factors, namely, (1) torque, (2) screw head geometry, and (3) materials of the screw, abutment, and implant. Since, "torque" is the only factor that is in clinician's control, definitive guidelines need to be set. Mostly clinicians depend upon manufacturer's guidelines to apply preload, as its clamping ability depends upon many other factors such as screw geometry, materials, surface coatings, frictional forces, accuracy of thread matching, etc. Insufficient preload leads to screw loosening or component failures, and too high preload values can result in fracture of the screw or implant fixture or even abutment itself. ${ }^{3}$ In order to minimize the errors in preload values, many manufacturers supply an abutment screw along with the abutment dedicated only for clinical use.

Careful maintenance of abutment screws is the key for longterm implant-restorative success. This can be achieved by few simple precautionary steps as follows: (1) use the screw that is copacked with the prosthetic component; (2) never use lab screws in patients; (3) use correct tool kit; (4) use calibrated torque-wrench; (5) follow manufacturer's instructions on torque values; (6) be aware of insufficient or too high torque values; (7) make sure implant internal
Department of Prosthodontics, Division of Clinical Dentistry, School of Dentistry, International Medical University, Kuala Lumpur, Malaysia Corresponding Author: Pravinkumar G Patil, Department of Prosthodontics, Division of Clinical Dentistry, School of Dentistry, International Medical University, Kuala Lumpur, Malaysia, Phone: +60 1135022042, e-mail: pravinandsmita@yahoo.co.in

How to cite this article: Patil PG. Preloading and Maintenance of Implant Abutment Screws. Int J Prosthodont Restor Dent 2019;9(3):69.

Source of support: Nil

Conflict of interest: None

screw thread area is clear with debris and tissues; (8) make sure that implant is sufficiently stable; and (9) use precisely fitting screws. Few manufacturers provide commercially pure titanium abutment screws or even carbon or gold-coated abutment screws to improve their torque strength and performance. Prosthetic restorations should be checked regularly during recall visit. An abutment screw gets loosened due to one or more reasons like inadequate or excessive clamping, faulty screw thread design, damaged screwthreads, faulty occlusal loading, overloading, parafunctional habits etc. Retightening of the abutment screws. However, as there are no commonly shared guidelines for prosthetic aftercare check-ups, these can depend on the case and the clinician.

\section{References}

1. Glossary of Implant Dentistry III. International Congress of Oral Implantologists; 2018.

2. Jung RE, Zembic A, Pjetursson BE, et al. Systematic review of the survival rate and the incidence of biological, technical, and aesthetic complications of single crowns on implants reported in longitudinal studies with a mean follow-up of 5 years. Clin Oral Implants Res 2012;23(Suppl 6):2-21. DOI: 10.1111/j.1600-0501.2012.02547.x.

3. Gratton DG, Aquilino SA, Stanford CM. Micromotion and dynamic fatigue properties of the dental implant abutment interface. J Prosthet Dent 2001;85(1):47-52. DOI: 10.1067/mpr.2001.112796.

(-) The Author(s). 2019 Open Access This article is distributed under the terms of the Creative Commons Attribution 4.0International License (https://creativecommons. org/licenses/by-nc/4.0/), which permits unrestricted use, distribution, and non-commercial reproduction in any medium, provided you give appropriate credit to the original author(s) and the source, provide a link to the Creative Commons license, and indicate if changes were made. The Creative Commons Public Domain Dedication waiver (http://creativecommons.org/publicdomain/zero/1.0/) applies to the data made available in this article, unless otherwise stated. 